\title{
PHYSIOLOGICAL ROLE OF BONE MARROW ADULT STEM CELL CD133+
}

\author{
J. IRGASHEVA ${ }^{1}$, I. ALDYBIAT ${ }^{3}$, F.A. SHUKUROV ${ }^{1}$, M. MIRSHAHI ${ }^{2,3}$
}

1 Avicenna Tajik State Medical University, Dushanbe, Tajikistan

2 Tajikistan Academy of Science, Dushanbe, Tajikistan

3 Paris Sorbonne Cité University, Lariboisière Hospital, UMR Paris -7 and INSERLM U965, Paris, France

Objective: To analyses the in vitro comportment of the $\mathrm{CD}_{133^{+}}$cells and their profile for cytokines secretion.

Methods: Bone marrow samples were obtained from 5 healthy individuals. Mesenchymal stem cells $\mathrm{CD} 133^{+}$extracted by magnetic bead from human bone marrow mononuclear cells (BMMNCs). BMMNCs were isolated by density-gradient centrifugation over Ficoll-400. Isolated CD133+ cells were plated on $0.2 \%$ gelatin-coated wells in the presence of free culture medium for cytokines analysis and with rich culture medium for spherical stem cell cluster generation. The proteins detected by protein array from the three independent cell preparations were considered as bioactive proteins.

Results: Isolated $\mathrm{CD} 133^{+}$cells using magnetic bead present more than $87 \pm 6 \%$ and $8 \pm 5 \% \mathrm{CD} 34^{+}$cells as assessed by flow cytometry and differentiate into adherent cells. $\mathrm{CD} 133^{+}$cells generate spheroid cell clusters in rich culture medium. Biological classification of the bioactive proteins secreted by the primo culture of $\mathrm{CD}_{133^{+}} / \mathrm{CD} 34^{+} \mathrm{BMMNCs}$ after $36 \mathrm{~h}$ in conditioned culture medium showed the presence of several categories of cytokines. Among these, the cardiac hypertrophic factor, the pro-angiogenic factors, the pro-inflammatory factors, wound healing factors such as MMPs-TIMPs, the neurophilic factors, the morphogenetic proteins and hematopoietic growth factors can be mentioned.

Conclusion: Our results indicate that $\mathrm{CD} 133^{+}$extracted from BMMNCs secretes important bioactive proteins. The multiple properties of these cytokines undoubtedly offer many therapeutic advantages.

Key words: $\mathrm{CD}_{133^{+}}$stem cells, spheroids formation, bone marrow, cytokines, growth factors.

\section{ФИЗИОЯОГИЧЕСКАЯ РОЯЬ ВЗРОСЯЫХ СD133+ СТВОЯОВЫХ КЯЕТОК КОСТНОГО МОЗГА}

\author{
ДЖ. ИРГАШЕВА ${ }^{1}$, И. АДДИБИАТ ${ }^{3}$, Ф.А. ШУКУРОВ, М. МИРШАХИ ${ }^{2,3}$
}

1 Таджикский государственный медицинский университет им. Абуали ибни Сино, Душанбе, Республика Таджикистан

2 Академия наук Республики Таджикистан, Душанбе, Республика Таджикистан

3 Парижский университет Сорбонна Сите, больница Ларибиоайре, УМР Париж-7 и INSERLM U965, Париж, Франция

Цель: анализ биологического поведения $\mathrm{CD} 133^{+}$стволовых клеток in vitro и изучение их профиля при секреции цитокинов.

Материал и методы: образцы костного мозга были получены у 5 здоровых людей. Мезенхимальные CD133+ стволовые клетки были выделены магнитным шариком из мононуклеарных клеток костного мозга человека (МККМ). МкКМ были изолированы от других клеток центрифугированием в Ficoll-400. Выделенные (изолированные) клетки CD $133^{+}$высевали на 0,2\% желатине в лунках в присутствии свободной культуральной среды для анализа цитокинов и с богатой культуральной средой для генерации кластеров сферических стволовых клеток. Белки, обнаруженные белковой матрицей из трех независимых клеточных препаратов, считались биоактивными белками.

Результаты: согласно оценке проточной цитометрии выделенные магнитным шариком CD133+ клетки составили более $87 \pm 6 \%$, а $\mathrm{CD} 34^{+}$клеток было $8 \pm 5 \%$, которые в последующем дифференцировались в адгезивные клетки. Биологическая классификация биоактивных белков, секретируемых первичной культурой $\mathrm{CD} 133^{+} / \mathrm{CD} 34^{+}$МKKM после 36 часов в кондиционированной культуральной среде, выявила наличие нескольких категорий цитокинов. К ним отнесены сердечный гипертрофический, проангиогенные, провоспалительные факторы, факторы заживления ран, такие как MMPs-TIMPs, нейрофильные факторы, морфогенетические белки и факторы роста гемопоэза.

Заключение: результаты исследования показали, что CD133', выделенные из МКKM, высвобождают важные биоактивные белки. Многочисленные свойства этих цитокинов, несомненно, обладают многими терапевтическими преимуществами. Ключевые слова: $C D 133^{+}$стволовые клетки, образование сфероидов, костный мозг, цитокины, факторы роста.

\section{INTRODUCTION}

Tissue regeneration may be due to infiltration of stem cells, which differentiate into other cells [1]. Laboratory experiments and recent clinical trials suggest that cell-based therapies can improve in several organ functions [2-9], and the implications of this for tissues regeneration are causing great excitement. These new findings have stimulated optimism that the progression regenerative medicine with cell-based therapy $[4,6]$. Numerous studies have documented that transplantation of bone marrow derived cells following acute myocardial infarction and ischemic cardiomyopathy can lead to a reduction in infarct scar size and improvements in left ventricular function and perfusion [5]. Furthermore, the impact of successes may be affected by quality (progenitor source) and quantity of the cells, timing [10], route (intramuscular, intracoronary) and type of cardiomyopathy [11]. Bone marrow stem cells (BMSC) can differentiate into multiple cell types present in the heart [12]. Following a sex-mismatched transplantation constellation heart muscle tissue analyzed after autopsy, it was revealed that mesenchymal stem cells of the BM play a pivotal role in the development of mixed chimeric of cardiomyocytes and endothelial cells following transplantation [13]. Source of stem cell therapy for heart disease may come from hematopoietic (BM, peripheral blood, umbilical cord blood) progenitors, mesenchymal (BM, adipose tissues), skeletal (muscle), endothelial (BM, peripheral 
blood) and cardiac (infarct border, epicardium) cells [3]. These cells are characterized by a high potential of pluripotent activity and can participate in tissues remodeling by secretion of growth factors in an autocrine or paracrine manner. In an animal model (rat), two cell types, namely skeletal myoblasts or $\mathrm{CD}_{133^{+}}$progenitors led to improvement of cardiac function $[14,15]$. In human, we and other demonstrated that bone marrow $\mathrm{CD}_{13} 3^{+}$cells as a source of stem cell therapy can be used in several protocols for regenerative medicine (5). Here, we report that $\mathrm{CD}_{13} 3^{+}$cells isolated from bone marrow mononuclear cells, generates the spheroids and secrete a large array of regulatory proteins including several cytokines such as pro angiogenic factors, pro-inflammatory factors, matrix metalloproteinase and tissue inhibitor of metalloproteinases, neurophilic factors, morphogenetic proteins and hematopoietic growth factors.

\section{MATERIAL AND METHODS}

\section{Bone marrow specimens}

Bone marrow samples were obtained from 5 healthy individuals. All samples were obtained after informed consent of individual patients and in accordance with the rules of the revised Helsinki protocol. All participants provide their written consent to participate in this study. The ethics committees of Tajikistan health ministry gave its approval of the procedures fallowed and for undertaking this study.

\section{Cell preparation}

Bone marrow mononuclear cells (BMMNCs) were isolated ( $n=5$ ) by density-gradient centrifugation over Ficoll-400 (PAA Laboratories, Les Mureaux, France). The BMMNCs layer was collected and the monocyte /macrophage cells were eliminated by incubation of the cells with polystyrene surface. CD133+ was separated from BMMNCs by a magnetic bead separation method following the manufacturer's instructions (MACS; Miltenyi Biotec, France). Purity of isolated CD133+ was analyzed using fluorochrome-conjugated anti-CD133 monoclonal antibodies. These cell preparation contained CD34+ cells and their amount was quantified by immunocytochemistry using anti-CD34 monoclonal antibody (mAbs, Miltenyi Biotec, Paris, France). BMMNC derived $\mathrm{CD} 133^{+} / \mathrm{CD} 34^{+}$were studied in this work.

\section{Cell culture}

Isolated CD $133+$ cells were plated on $0.2 \%$ gelatin-coated wells (Sigma, Saint-Quentin Fallavier, France) and maintained in endothelial cell basal medium MV2 (ECBM MV2, Promocell, Heidelberg,Germany) supplemented with ECBM-MV2 complemented (Promocell). At 6 days of culture, non-adherent cells were removed, new media was applied, and the culture was further maintained through days 21. The spheroids generation performed using mesenchymal stem cell medium complemented by growth factors (promocells). The spheroid are detectable after 48 to $72 \mathrm{~h}$.

\section{Cytokine array}

In order to analyze the in vitro secretion of bioactive proteins by bone marrow stem cells, the supernatant of BMC-D133+cells $(n=3)$ were analyzed using a protein cytokine array (RayBio ${ }^{\circledR}$ Human Cytokine Antibody). This technique is based on the principle of "sandwich immunoassay". It comprises essentially of screening, in duplicate, 174 different membrane coupled anti-cytokines along with appropriate controls (experiments repeated 3 times). BMC-D133+ cells (106 cells per $\mathrm{mL}$ ) were incubated in RPMI-1640 without fetal calf serum at $37^{\circ} \mathrm{C}$ in a humidified atmosphere of 5\% CO2 for 24 hours. Supernatants containing cytokines were retrieved and the cytokines were allowed to couple with their specific antibodies previously immobilized on membranes. Membranes were saturated for 2 hours at room temperature with bovine serum albumin (BSA). Incubation of array membranes with supernatants (along with controls) was carried out overnight at $4^{\circ} \mathrm{C}$ using corresponding antibodies. After several successive washes, membranes were incubated in the presence of a mixture of antibodies and anticytokines biotinyled at $4^{\circ} \mathrm{C}$ overnight. Streptavidine, coupled with HRP, was added on the membranes for 2 hours at room temperature. The presence of antibody coupled proteins was revealed by applying ECL (Enhanced Chemo-luminescence) to the membranes, according to the recommendations of the manufacturer. Membranes were then exposed to a photosensitive film (Kodak, x-omat AR-USA). The intensity of chemo-luminescence captured on the photosensitive film was measured and recorded (see figure 1). After substracting the background noise, the results were expressed as a ratio of chemoluminescence intensity of experimental versus negative control spots. The positive control was considered as 1 . Less than - 2 ratio values indicated a reduction of the cytokine and a value greater than +2 indicated an increase in cytokine expression. The proteins detected by protein array from the three independent cell preparations were considered as bioactive proteins and presented in table 1.

\section{RESULTS}

BMMNC CD133 $^{+}$differentiate into adherent cells

BMMNCs were isolated from bone marrow of different normal donors $(n=5) . \mathrm{CD}_{13} 3^{+}$cells were isolated and their purity was found to be more than $87 \pm 6 \%$ as assessed by flow cytometry. These mesenchymal cell preparations contained also $8 \pm 5 \% \mathrm{CD} 34^{+}$cells.

$\mathrm{CD} 133^{+} / \mathrm{CD} 34^{+} \mathrm{BMMNCs}$ were cultured in vitro under specific conditions as described in material and methods section. Figure 2 presents the $\mathrm{CD} 133^{+} / \mathrm{CD} 34^{+}$BMMNCs after 3 days $(\mathrm{A}), 6$ days $(\mathrm{B})$, and 2 weeks (C), and 3 weeks (D) in culture. After 3 weeks in culture, adherent cells displaying totally different morphological aspects. Indeed, certain cells were long and frayed while others were rather small (result not shown).

The adherent cell population generates the spheroid cell clusters

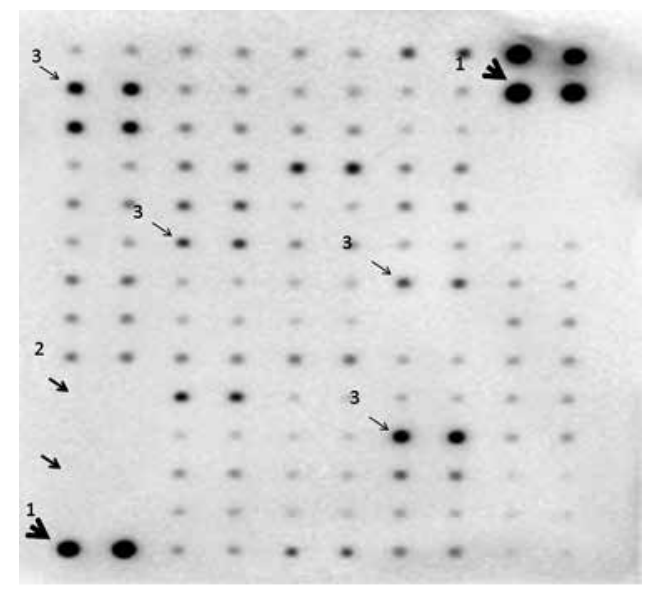

Figure 1 The luminescence plate reveled by different anti human cytokines antibodies. The arrow (1) present the positive control, the arrow (2) for negative control and the arrows (3) present examples of cytokines detected in this experiments. All test presented in duplicates 


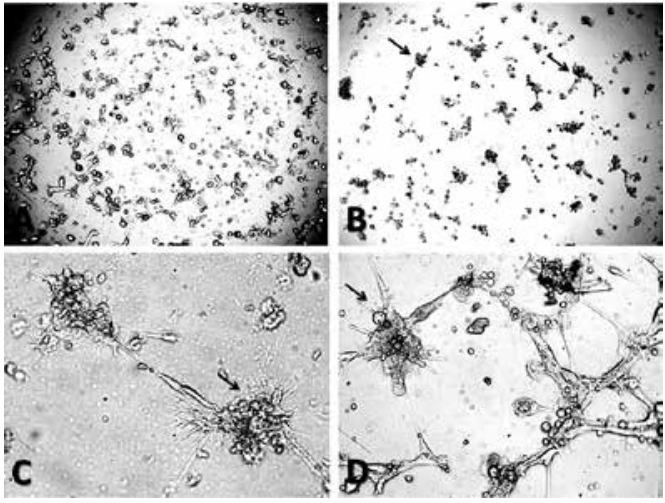

Figure $2 \mathrm{CD} 133+$ cell extracted from normal human bone marrow in rich culture medium (see material and methods): Primary culture after 3 days (A), after 6 days (B), after 2 weeks (C) and after 3 weeks (D). Magnifications $x 80$ for $A$ and $B, x 160$ for $C$ and $D$.

When the bone marrow mesenchymal cell (originally $\mathrm{CD} 133^{+}$) cultivated in rich culture medium (mesenchymal culture medium, promocells, France), adherent cell population generates the spheroid cell clusters after 2 weeks. (Figure 3, A). The same results obtained when the established mesenchymal cell was used. The spheroids shape was appeared after $72 \mathrm{~h}$ (Figure $3, \mathrm{~B}$ ). The generation of spheroid from BMMNC-CD133+ cells confirms the stem property of $\mathrm{CD}_{133^{+}}$cells from human bone marrow.

\section{The adherents cells secrete bioactive proteins}

After 3 days of culture, three samples of $\operatorname{CD} 133^{+} / \mathrm{CD} 34^{+}$ BMMNCs cells from 3 different donors were incubated with conditioned medium at $37^{\circ} \mathrm{C}$ for $36 \mathrm{~h}$. The supernatants were tested by Ray-Bio protein array. As presented in table-1, $\mathrm{CD}_{133^{+}}$/ CD34+ BMMNCs secrete in vitro an important bioactive proteins such as 1) cardiotropin-1, 2) angiogenic factors such as angiogenin, angiopoeitin-2, basic fibroblast growth factor (FGFb), placenta growth factor (PGF), vascular endothelial growth factor-121 (VEGF), VEGF-165 and VEGF-D, 3) neurogenic factors as agouti-related protein (AGRP), brain-derived neurotropic factor (BDNF), human ciliary neurotrophic factor, basic nerve growth factor (NGFb), amphiregulin, neurotrophin-3 and 4, activin A and prolactin, 4) morphogenetic proteins such as bone morphogenetic protein, BMP-4, 5, 6 and 7, 5) several pro-inflammatory such as 1-309 (CCL-1), monocyte chemoattractant protein-1 (MCP-1), MIP-1a , RANTES, IL-1ra (Interleukin-1receptor antagonist), CXCL-16, MIF (Macrophage migration inhibitory factor) and sTNFR-1(soluble tumor necrosis factor receptor-1) as well as 6) remodeling factors such as matrix metalloproteinase (MMP) and tissue inhibitor of metalloproteinases (TIMP) and finally, 6) hematopoietic growth factors including interleukin-3 (IL-3), granulocyte-macrophage colony-stimulating factor (GM-CSF), macrophage colony-stimulating factor,(M-CSF), granulocyte colony-stimulating factor (G-CSF), and thrombopoietin (TPO). However, several cytokines were absent among the bioactive proteins tested (results not shown).

\section{Discussion}

Bone marrow CD133-positive $\left(\mathrm{CD} 133^{+}\right)$cells possess strong hematopoietic and angiogenic capacity and can differentiate into several tissue types such as adipocyte, chondrocyte, osteocyte, neurocyte and myocyte [16]. In this study, we noted that when we
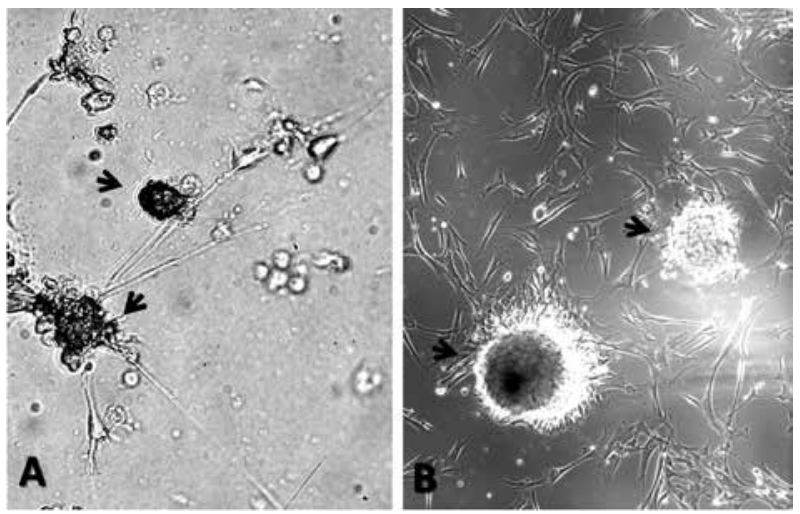

Figure 3 Spheroids formation (arrow) by bone marrow CD133+ cells in conditional medium after two week $(A)$ and with stablished bone marrow mesenchymal cells after $72 \mathrm{~h}(B)$. In this picture 2 spheroids generated by the mesenchymal adherent cells (arrows).

use magnetic microbed technique for enrichment of $\mathrm{CD} 133^{+}$cells, the cell preparation also contained $\mathrm{CD} 34^{+}$progenitor cells. $\mathrm{CD}_{133^{+}} /$ CD34+ BMMNCs with specific medium can differentiate into several cells types such as endothelial cells, adipocyte, osteocyte, neurocyte and myocyte (results not shown). These results confirm the earlier observation concerning pluripotent nature of $\mathrm{CD}_{13} 3^{+} / \mathrm{CD}_{3} 4^{+}$ BMMNCs [16].

We analyzed the secretion of bioactive proteins of $\mathrm{CD}_{133^{+}}$/ $\mathrm{CD}_{3}{ }^{+} \mathrm{BMMNCs}$ in vitro. The proteins secreted are angiogenic and neurogenic factors, morphogenetic proteins and several growth factors and hematopoietic growth factors. One of the interesting bioactive proteins secreted by these cells is Cardiotrophin-1 (CT-1) which is a member of the interleukin- 6 type cytokine family (table $1, \mathrm{~A})$. These cytokines mediate overlapping pleiotropic actions in a variety of cell types including cardiac myocytes, hepatocytes, megakaryocytes, osteoclasts, and neuronal cells. It is important to note that CT-1 was shown to specifically protect the cardiac myocytes from ischemic damage [17]. The role of $\mathrm{CD} 133^{+}$cells in undertaking repair of heart regions is multistep and the intervention of several factors during the process undeniably reinforces our choice of $\mathrm{CD}_{133^{+}}$cells for the treatment protocol in heart disease.

CD133 ${ }^{+} / \mathrm{CD} 34^{+} \mathrm{BMMNCs}$ have also a strong pro-angiogenic capacity (table 1, B) as it secretes several factors such as angiogenin, angiopoeitin-2, VEGF-121 and 165, VEGF-D, PLGF (placenta growth factor) and b-FGF (basic fibroblast growth factor). These factors could be involved in angiogenesis/ revascularization after cell therapy [18].

Angiogenin (Ang) also known as ribonuclease 5 is a small 123 amino acid protein that in humans is encoded by the ANGgene. Angiogenin is a potent stimulator of new blood vessels through the process of angiogenesis. Angiopoeitin- 2 is essential during embryonic vessel assembly and maturation, and functions as a key regulator of adult vascular homeostasis. VEGF is a signal protein produced by cells that stimulates vasculogenesis and angiogenesis. It is part of the system that restores the oxygen supply to tissues when blood circulation is inadequate. VEGF's normal function is to create new blood vessels during embryonic development, new blood vessels after injury, muscle following exercise, and new vessels (collateral circulation) to bypass blocked vessels. PLGF is a member of the VEGF sub-family - a key molecule in angiogenesis and vasculogenesis, in particular during embryogenesis. The main source of PGF during pregnancy is the placental trophoblast. PGF is also expressed in many other tissues, including the villous trophoblast. We have 
Table 1 Biological classification of the bioactive proteins secreted by the primo culture of CD133+/CD34+ BMMNCs (87 $\pm 4 \% / 8 \pm 5 \%)$ after $36 \mathrm{~h}$ in conditioned culture medium

A - cardiac hypertrophic factor
CT-1 (Cardiotrophin)

\section{B - Pro-angiogenic factors}

Angigenin

Angiopoietin-2

b-FGF (Basic fibroblast growth factor)

PLGF (Placenta growth factor)

VEGF-121 (Vascular endothelial growth factor-121)

VEGF165 (Vascular endothelial growth factor-165)

VEGF-D (Vascular endothelial growth factor-D)

\section{C - Pro-inflammatory factors}

I-309 (CCL-1 (C-C motif) ligand-1)

MCP-1 (CCL-2 (C-C motif) ligand-2)

MIP-1a (CCL-4 (C-C motif) ligand-4)

RANTES (CCL-5 (C-C motif) ligand-5)

IL-1ra (Interleukin-1receptor antagonist)

CXCL-16 (C-X-C motif) ligand-16)

MIF (Macrophage migration inhibitory factor)

sTNFR-1(Soluble tumor necrosis factor receptor-1)

\section{D - MMPs-TIMPs}

MMP-1(Matrix metalloproteinase-1)

MMP-3 (Matrix metalloproteinase-3)

MMP-9 (Matrix metalloproteinase-9)

MMP-13 (Matrix metalloproteinase-13)

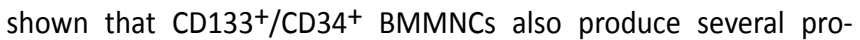
inflammatory factors including chemokines I-309 (CCL-1), MCP1 (monocyte chemoattractant protein-1 or CCL-2), Macrophage Inflammatory Proteins (MIP-1) family or CCL-4, RANTES (CCL-5), interleukine-1 receptor antagonist (IL-1ra), CXCL-16, Macrophage Migration Inhibitory Factor (MIF) and soluble tumor necrosis factorreceptor (sTNFR-1). These pro inflammatory factors secreted by the stem cells (table $1, \mathrm{C}$ ) in all probability intervene in tissue remodeling in the damaged zone.

Bone marrow stem cells secrete several interesting Matrix metalloproteinase (MMPs) such as MMP1 (collagenase), MMP3 (stromolysin), MMP9 (gelatinase) and MMP13 (collagenase) and their inhibitors (TIMPs); TIMP1, TIMP2 and TIMP4. MMPs belong to a larger family of proteases known for their role in remodeling of extracellular matrix and affecting cell behaviors such as cell proliferation, migration, differentiation and angiogenesis. The tissue inhibitors of metalloproteinases are naturally occurring proteins that specifically inhibit matrix metalloproteinases, and contribute towards maintaining a balance between matrix destruction and matrix formation (table 1, D). The presence of these specialized family proteins, secreted by stem cells, goes in favor of their importance in matrix guided remodeling of tissue substrates.

As presented in table 1 (3E), CD133 ${ }^{+} / \mathrm{CD}_{3} 4^{+}$BMMNCs secrete neurophilic and brain bioactive proteins. The neurophilic factors essentially AGRP (Agouti-related protein), BNDF (Brain-
TIMP-1 (Tissue inhibitor of metalloproteinases-1)

TIMP-2 (Tissue inhibitor of metalloproteinases-2)

TIMP-4 (Tissue inhibitor of metalloproteinases-4)

\section{E - Neurophilic factors}

AGRP (Agouti-related protein)

BDNF (Brain-derived neurotrophic factor)

CTNF (Human ciliary neurotrophic factor)

b-NGF (Basic nerve growth factor)

AREG (Amphiregulin)

NT-3 (Neurotrophin-3)

NT-4 (Neurothropin-4)

Activin A (promotes neural cell differentiation)

Prolactin (promotes neurogenesis in maternal and fetal brains)

\section{F - Morphogenetic proteins}

BMP-4 (Bone morphogenetic protein-4)

BMP-5 (Bone morphogenetic protein-5)

BMP-6 (Bone morphogenetic protein-6)

BMP-7 (Bone morphogenetic protein-7)

\section{G - Hematopoietic growth factors}

IL-3 (Interleukin-3)

GM-CSF (Granulocyte-macrophage colony-stimulating factor)

M-CSF (Macrophage colony-stimulating factor)

G-CSF (Granulocyte colony-stimulating factor)

THPO (Thrombopoietin )

derived neurotrophic factor), CNTF (human ciliary neurotrophic factor), AREG (Schwannoma-derived growth factor, Amphiregulin) is a growth factor as well as a mitogen for astrocytes, Schwann cells and fibroblasts [19], b-NGF (basic nerve growth factor), NT-3 (neurotrophin-3), NT-4 (Neurotrophin-3), activin A and prolactin (tab-1D). These factors promote neurogenesis and neural cell differentiation [20]. These factors are of importance in establishing/ re-establishing axis of control between the myocardium and the nerve innervations. The secretion of neurophilic factor by CD133 cells is in favor of their utilization for nerve regeneration medicine.

The morphogenetic proteins produced by $\mathrm{CD} 133^{+} / \mathrm{CD} 34^{+}$ BMMNCs are BMP-4, BMP-5, BMP-6 and BMP-7 (table 1, F). These proteins constitute a group of important morphogenetic signals, needed in orchestering tissue architecture throughout the body [21]. They are the major actors during embryonic development, particularly in embryonic patterning and early skeletal formation [22]. They also participate in vasculature-guided neuronal migration under both normal and pathological conditions [23]. Once again, the coordinated action of angiogenic, nuerogenic and morphogenic provided by $\mathrm{CD} 133^{+} / \mathrm{CD} 34^{+}$BMMNCs seem necessary in the cellular mechanism leading to recovery of damage in the organs. Hematopoietic growth factors secreted by these cells indicate their benefic effect for bone marrow regeneration (table 1, G). Interleukin-3 (IL-3) can improve the body's natural response to disease as part of the immune system [24]. IL-3 stimulates the 
differentiation of multipotent hematopoietic stem cells into myeloid progenitor cells or, with the addition of IL-7, into lymphoid progenitor cells. In addition, IL-3 stimulates proliferation of all cells in the myeloid lineage (granulocytes, monocytes, and dendritic cells), in conjunction with other cytokines, e.g., erythropoietin (EPO), gra nulocyte macrophage colony-stimulating factor (GM-CSF). GM-CSF is now best viewed as a major regulator governing the functions of granulocyte and macrophage lineage populations at all stages of maturation.

\section{CONCLUSSION}

In conclusion, our results indicate that $\mathrm{CD} 133^{+}$BMMNCs secrete important bioactive proteins and can be an excellent choice for cell therapy in regenerative medicine.

\section{REFERENCES}

1. Leri A, Kajstura J, Anversa P. Role of cardiac stem cells in cardiac pathophysiology: a paradigm shift in human myocardial biology. Circ Res. 2011;109(8):941-61. Available from: http://dx.doi.org/10.1161/ CIRCRESAHA.111.243154. Review.

2. Abdel-Latif A, Bolli R, Tleyjeh IM, Montori VM, Perin EC, Hornung CA, et al. Adult bone marrow-derived cells for cardiac repair: a systematic review and meta-analysis. Arch Intern Med. 2007;167(10):989-97. Review.

3. Hoover-Plow J, Gong Y. Challenges for heart disease stem cell therapy. Vasc Health Risk Manag. 2012;8:99-113. Available from: http://dx.doi. org/10.2147/VHRM.S25665. Epub 2012 Feb 17. Review.

4. Segers VF, Lee RT. Stem-cell therapy for cardiac disease. Nature. 2008;451(7181):937-42. Available from: http://dx.doi.org/10.1038/nature 06800. Review.

5. Kurbonov U, Dustov A, Barotov A, Khidirov M, Mirojov G, Rahimov Z, et al. Intracoronary infusion of autologous CD133(+) cells in myocardial infarction and tracing by Tc99m MIBI scintigraphy of the heart areas involved in cell homing. Stem Cells Int. 2013;2013:582527. Available from: http://dx.doi. org/10.1155/2013/582527.

6. Gersh BJ, Simari RD, Behfar A, Terzic CM, Terzic A. Cardiac cell repair therapy: a clinical perspective. Mayo Clin Proc. 2009;84(10):876-92.

7. Ranjeet Singh Mahla. Stem cells applications in regenerative medicine and disease therapeutics. Int J Cell Biol. 2016; 2016: 6940283. Available from: http://dx.doi.org/10.1155/2016/6940283.

8. Weiss DJ. Current status of stem cells and regenerative medicine in lung biology and diseases. Stem Cells. 2014;32(1):16-25. Available from: http:// dx.doi.org/10.1002/stem.1506.

9. Richardson SM, Kalamegam G, Pushparaj PN, Matta C, Memic A, Khademhosseini $A$, et al. Mesenchymal stem cells in regenerative medicine: Focus on art icular cartilage and intervertebral disc regeneration. Methods. 2016;99:69-80. Available from: http://dx.doi.org/10.1016/j.ymeth.2015.09.015.

10. Aicher A, Heeschen C, Sasaki K, Urbich C, Zeiher AM, Dimmeler S. Low-energy shock wave for enhancing recruitment of endothelial progenitor cells: a new modality to increase efficacy of cell therapy in chronic hind limb ischemia. Circulation. 2006;114(25):2823-30. Epub 2006 Dec 4.

11. Martin-Rendon E, Brunskill SJ, Hyde CJ, Stanworth SJ, Mathur A, Watt $\mathrm{SM}$. Autologous bone marrow stem cells to treat acute myocardial infarction: a systematic review. Eur Heart J. 2008;29(15):1807-18.

12. Liao $R$, Pfister $O$, Jain $M$, Mouquet $F$. The bone marrow--cardiac axis of myocardial regeneration. Prog Cardiovasc Dis. 2007;50(1):18-30. Review.

13. Thiele J, Varus E, Wickenhauser C, Kvasnicka HM, Lorenzen J, Gramley F, et al. Mixed chimerism of cardiomyocytes and vessels after allogeneic bone marrow and stem-cell transplantation in comparison with cardiac allografts. Transplantation. 2004;77(12):1902-5.

14. Agbulut $\mathrm{O}$, Vandervelde S, Al Attar N, Larghero J, Ghostine S, Léobon B, et al. Comparison of human skeletal myoblasts and bone marrow-derived $\mathrm{CD} 133+$ progenitors for the repair of infarcted myocardium. J Am Coll Cardiol. 2004;44(2):458-63.

15. Taylor DA, Atkins BZ, Hungspreugs $P$, Jones TR, Reedy MC, Hutcheson KA, et al. Regenerating functional myocardium: improved performance after skeletal myoblast transplantation. Nat Med. 1998;4(8):929-33. Erratum in: Nat Med 1998 Oct;4(10):1200.

16. Tondreau T, Meuleman N, Delforge A, Dejeneffe M, Leroy R, Massy M, et al. Mesenchymal stem cells derived from CD133-positive cells in mobilized peripheral blood and cord blood: proliferation, Oct4 expression, and plasticity. Stem Cells. 2005;23(8):1105-12. Epub 2005 Jun 13.

17. Jougasaki M. Cardiotrophin-1 in cardiovascular regulation. Adv Clin Chem. 2010;52:41-76. Review.

18. Lohela M, Bry M, Tammela T, Alitalo K. VEGFs and receptors involved in angiogenesis versus lymphangiogenesis. Curr Opin Cell Biol. 2009;21(2):15465. Available from: http://dx.doi.org/10.1016/j.ceb.2008.12.012. Epub 2009 Feb 21.Review.

19. Wilson KJ, Mill C, Lambert S, Buchman J, Wilson TR, Hernandez-Gordillo V, et al. EGFR ligands exhibit functional differences in models of paracrine and autocrine signaling. Growth Factors. 2012;30(2):107-16. Available from: http://dx.doi.org/10.3109/08977194.2011.649918. Epub 2012 Jan 20. Review.

20. Park $\mathrm{H}$, Poo MM. Neurotrophin regulation of neural circuit development and function. Nat Rev Neurosci. 2012;14(1):7-23. Available from: http://dx.doi. org/10.1038/nrn3379.

21. van Wijk B, Moorman AF, van den Hoff MJ. Role of bone morphogenetic proteins in cardiac differentiation. Cardiovasc Res. 2007;74(2):244-55. Epub 2006 Nov 21. Review.

22. Wan M, Cao X. BMP signaling in skeletal development. Biochem Biophys Res Commun. 2005;328(3):651-7. Review.

23. Sun $Y$, Fei $T$, Yang $T$, Zhang $F$, Chen YG, Li H, Xu Z. The suppression of CRMP2 expression by bone morphogenetic protein (BMP)-SMAD gradient signaling controls multiple stages of neuronal development. J Biol Chem. 2010;285(50):39039-50. Available from: http://dx.doi.org/10.1074/jbc. M110.168351. Epub 2010 Oct 6.

24. Yang YC, Ciarletta AB, Temple PA, Chung MP, Kovacic S, Witek-Giannotti JS, et al. Human IL-3 (multi-CSF): identification by expression cloning of a novel hematopoietic growth factor related to murine IL-3. Cell. 1986;47(1):3-10.

\section{(i) author information}

Irgasheva Jamila, Doctorant at the Department of Normal Physiology, Avicenna TSMU

Aldybiat Iman, PhD, Post Doctorant in Paris Sorbonne Cité University, Lariboisière Hospital, UMR Paris-7 and INSERLM U965, Paris, France

Shukurov Firuz Abdufattoevich, Doctor of Medical Sciences, Full Professor, Professor of the Department of Normal Physiology, Avicenna TSMU

Mirshahi Massoud, Professor, MD, PhD, Paris Sorbonne Cité University, Lariboisière Hospital, UMR Paris -7 and INSERLM U965, Member of Tajikistan Academy of Science

\section{(i) СВЕДЕНИЯ ОБ АВТОРАХ}

Иргашева Джамиля, докторант кафедры нормальной физиологии ТГМУ им. Абуали ибни Сино

Алдибиат Иман, PhD, научный сотрудник, Парижский университет Сopбонна Сите, больница Ларибиоайре

Шукуров Фируз Абдуфаттоевич, д.м.Н., профессор, профессор кафедрь нормальной физиологии ТГМУ им. Абуали ибни Сино

Миршахи Масуд, MD, PhD, профессор, Парижский университет Сорбонна Сите, больница Ларибиоайре 
Information about the source of support in the form of grants, equipment, drugs

The authors did not receive financial support from the companies producing medical drugs and manufacturing medical equipment.

Competing interests: none

\section{$\triangle$ ADDRESS FOR CORRESPONDENCE:}

M. Mirshahi MD, PhD

Université de Sorbonne Paris Cité

UMR Paris 7, INSERM U965

Carcinose, Angiogenèse et

Recherche Translationnelle

L'Hôpital Lariboisière

41 Bd de la Chapelle

75010, Paris, France

Tel.: 0033153216775

Fax: 0033153216739

E-mail: massoud.mirshahi@inserm.fr
Received $\quad 11.01 .2017$

Accepted $\quad 30.06 .2017$
Информация об источнике поддержки в виде грантов, оборудования, лекарственных препаратов

Финансовой поддержки со стороны компаний-производителей лекарственных препаратов и медицинского оборудования авторы не получали.

Конфликт интересов: отсутствует.

\section{$\triangle$ АДРЕС ДЛЯ КОРРЕСПОНДЕНЦИИ:}

Massoud Mirshahi MD, PhD

Université de Sorbonne Paris Cité

UMR Paris 7, INSERM U965

Carcinose, Angiogenèse et

Recherche Translationnelle

L'Hôpital Lariboisière

$41 \mathrm{Bd}$ de la Chapelle

75010, Paris, France

Tel.: 0033153216775

Fax: 0033153216739

E-mail: massoud.mirshahi@inserm.fr

\section{ВКЛАД АВТОРОВ}

Разработка концепции и дизайна исследования: ММ, ШФА Сбор материала: ИД, АИ

Статистическая обработка данных: ИД

Анализ полученных данных: ММ, ШФА, ИД

Подготовка текста: MM, АИ

Редактирование: ММ

Общая ответственность: МM

Поступила

11.01.2017

Принята в печать

30.06 .2017 